\title{
Distinguishing between penile and buccal cells using different staining techniques
}

\begin{abstract}
The identification of epithelial cells in sexual offenses has faced difficult times over the past two decades in forensic science. For this reason there has been a demand for a method that can conclusively distinguish between epithelial cells since they have been known to be morphologically similar in their structure according to previous research. This study was aimed to develop a technique using histological staining methods try to, and distinguish between penile and buccal cells from a sexually assaulted victim perspective. Samples were collected from male and females and stored according to the Human Tissue Act (2003). The first 20 samples, each cell type was extracted using water, centrifuged then pelleted on to microscopic slides. The slides were then placed onto hotplate at $50^{\circ} \mathrm{C}$ for 2 minutes to dry and left overnight to cool. Each staining method, Lugol's Iodine, Papanicolaou (Pap) and Haematoxylin and Eosin (H\&E) stain was applied to three slides for buccal and penile cells to observe the cells under a high power microscope (400x). Separate 20 samples were smeared onto slides and then stained using the staining procedures. Extracted cells with water did not produce any positive stained cells after staining but smeared cells showed positive stained cells with a total of 515 cells. Lugol's Iodine did not indicate positive stained penile cells but 13 positive stained buccal cells were found. Pap Stain had 18 positive stained buccal cells with no positive stained penile cells. H\&E had 120 positive stained buccal cells and negative for penile cells. When the two cells were combined, Pap stain showed presence of 71 unknown positive stained cells which could be indication of penile cells and 108 positive stained buccal cells. Cells combined with H\&E stain had 185 buccal cells but did not detect any penile cells. These results suggested that Pap Stain was a successful histological staining method for distinguishing between penile and buccal cells and could potentially be used in the near future for sexual offenses in forensic casework
\end{abstract}

Volume 2 Issue 5 - 2016

\author{
Rashid T Lutalo \\ University of Teesside, School of Science of Engineering, UK
}

Correspondence: Rashid T Lutalo, University of Teesside, School of Science of Engineering, UK, Tel 07983 I56392, +4475407473265,

Email r.lutalo@yahoo.co.uk, M2101548@live.tees.ac.uk

Received: June 06, 2016 | Published: July 27, 2016

\section{Introduction}

Many countries in the 1970s introduced reforms in rape law with differing focus and extensiveness and along with these reforms, the descriptions of rape and sexual intercourse were broadened to include a series of sexual aggravated offenses such as the expansions of intercourse, which included oral and anal penetration in addition to vaginal penetration. ${ }^{1,2}$ In England and Wales towards the late 1970s, a number of reforms took place with a major change which introduced the principle of "without her consent".,3 The definitions of rape were then expanded further during mid 1990s in England and Wales which included male and marital rape. ${ }^{3}$ When further sexual offenses were introduced with the launch of the Sexual Offenses Act (2003) such 'as assault by penetration' this expanded the definition of rape. ${ }^{5}$

In the past forensic science has faced major issues relating to cases of sexual offenses when a spermatozoon is not available for forensic analysis. Chen et al. ${ }^{6}$ explained that even in semen stains, they would still contain a combination of epithelial cells such as vaginal, buccal and penile. However, the recovery and techniques used to examine or to distinguish between the cells is complex and for these reasons there has always been a demand for a method that can conclusively distinguish between penile and buccal cells which are common cells that are likely to transfer in sexual activity. ${ }^{7}$ Previous research has revealed that all three cell types, skin, buccal and vaginal are categorised as stratified squamous epithelium and contain similar protective functions and protein expressions hence they are known to be morphologically similar. ${ }^{8}$ In the UK, sexual assault of females remains undisclosed and the reasons for this can be multi-factorial, which include fear of repercussions by the perpetrator, misplaced feelings of guilt or shame amongst family members especially when asked to recall past events and the lack of faith in the criminal justice system. ${ }^{9}$

On the other hand, from the forensic scientist's perspective, the delay in engaging with police following sexual assault, will adversely affect the quality of forensic cellular evidence required for examination..$^{10}$ As Wardle ${ }^{9}$ stated, after the incident of sexual assault, the collection of cellular material should not be any longer than two days. Therefore it is paramount that the evidence collected from the victim is used by forensic scientists, to provide evidential information which may confirm whether or not there was any unconsensual sexual contact. ${ }^{11}$ The sense of feeling distressed, unsafe, vulnerable are some of the psychological processes victims go through after experiencing such offences by the perpetrator and for these reasons, victims should be aware that centres such as the Sexual Assault Referral Centre (SARCs) have been implemented specifically for them to feel comfortable about discussing events and to collect any evidence needed for the casework. ${ }^{12}$ 
The problem concerning sexual assaults still occurs higher in females even up to this current day according to the Office for National Statistics ${ }^{13}$ report. In England and Wales, years 2009/10, 2010/11, 2011/12 statistics have shown an average of 85,000 female victims who have reported being victims of serious sexual offense, which is estimated at around $0.5 \%$ of reported victims on average per year. The report also states that female victims who did not report the offense had this perception that the police would not be able to solve anything even if they reported the offense and victims considered it as a private and family matter. ${ }^{13}$ Hence this leads back to the studies carried out by Cartwright et al., ${ }^{12}$ Cybulska et al., ${ }^{10}$ Wardle ${ }^{9}$ about the victims perspective not being able to engage with police investigators which leaves the majority of crimes unsolved.

Lugol's iodine has been known in previous research that positive glycogen epithelial cells are a good indicator of recent sexual intercourse if they are found to be present on male glans penis, and has been used to identify glycogenated vaginal cells since they contain high content of glycogen than in all other epithelial cells and was accepted to be used as evidence in court. ${ }^{14}$ However, Dettemeyer ${ }^{15}$ also discovered that the same is found in the male efferent urinary tract, hence it was disclosed that Lugol's iodine is not suitable to forensically determine vaginal epithelial cells on penis specimens following sexual intercourse. Nevertheless, buccal cells which are also found in saliva, it was discovered similarly that the cells reacted in the same way with similar morphological features as vaginal cells after using the Lugol's iodine stain. ${ }^{8}$

Studies have published that cells can also be differentiated using different techniques, for example Y-STR analysis, which identifies Y-chromosomes in males cells from intimate swabs collected after a sexual offense and has proven to be effective in forensic casework. ${ }^{16,17}$ Although the Y-STR technique can isolate male cells in sexual assault casework, this method cannot distinguish whether the male cells are penile or buccal cells since it has been known by Keating ${ }^{18}$ that males have used saliva as lubricant previously in sexual offenses. Identification of sex exfoliated cells by using the aceto-orcein test on buccal smears has also been proven to be useful if applied in forensic casework, which is based on the visualisation of chromosomes of densely stained chromatin in female cells. ${ }^{19}$ The study showed effective results. However issues still arise, for instance, where unconsensual oral and penile intercourse has occurred on female victim, applying this method would still be insignificant to support whether or not the evidence suggests the events occurred from the act of oral or penile intercourse from a penile swab because the technique can only identify female chromatin present in the cells..$^{18,20}$

Epithelial cells can be differentiated cytological e.g. keratinous epithelial cells, non-keratinised squalors of buccal mucosa, as well as epithelial cells from the penis using different staining methods that are specific to the content within epithelial cells such as glycogen. ${ }^{15}$ Unlike other stains, Lugol's Iodine and Haematoxylin and Eosin (H\&E), no research has been conducted yet using Papanicolaou stain (Pap) for distinguishing between epithelial cells whether its buccal, vaginal or penile cells. Pap stain is a widely used as a polychrome technique in human medicine but particularly in vaginal cytology and also for exfoliated cells. ${ }^{21}$ Pap stain is known for its ability to yield detailed information regarding nucleoli and chromatin pattern the cell nuclei and its method involves more fixation and multi-step staining procedures compared to most stains. ${ }^{22}$ Therefore the purpose of this research study is to identify the issues and the complexities in sexual offenses by performing a series of histological staining procedures to develop a method using the Lugol's Iodine, Pap Stain and H\&E to conclusively and determine whether the use of these staining techniques can be applied distinguish between penile and buccal cells which could be used in sexual offenses in forensic casework.

\section{Materials and methods}

\section{Cell extraction}

40 samples of penile and buccal cells of male were collected and stored according to the Human Tissue Act (2003). For each buccal swab, the piece of cotton was cut around the end of the cotton swab using a scalpel. The piece of cotton was then placed into eppendorff tube and adding a few drops of sterile water. The tube was then placed into a centrifuge at $1000 \mathrm{x}$ g for about 10 minutes to allow efficient extraction of cells. The extracted cells were then transferred onto a microscopic slide and pelleted using a plastic pasture pipette. The cells were then placed onto hotplate for about 2 minutes at $50^{\circ} \mathrm{C}$ then left to fully dry overnight in a fume cupboard. The same procedure was repeated for the extraction of penile cells. During this extraction phase, three buccal and penile cell slides were prepared so that each of the three stains can be applied separate first before combining cells.

\section{Histological staining}

Lugol's iodine: It was prepared by dissolving $5 \mathrm{~g}$ of potassium in water, however chlorine solution was available as Lugol's Iodine is used instead. The recovered dried samples were collected from previous experiment. A buccal cell sample was stained with Lugol's Iodine about three drops and placed onto a hotplate for about 2 minutes at $50^{\circ} \mathrm{C}$ to dry. The same procedure was also carried out for penile cell sample.

Pap stain: Ethanol fixation/acid formalin-free fixative was placed onto a buccal cell sample and left for about 15 minutes and then briefly rinsed with tap water. Then three drops of $70 \%$ of ethanol was added for about 4 minutes followed by three drops of $50 \%$ of ethanol for about 4 minutes and then briefly rinsed with tap water. The sample was then flooded with Haematoxylin for about 8 minutes and then rinsed briefly with tap water. Acid alcohol was then replaced for 10 seconds then dehydrated in absolute alcohol (x2) following the addition of orange $\mathrm{G}$ for about 20 seconds and then rinsed briefly with tap water. EA-50 Papanicolaou was added for about 4 minutes, then rinsed in with absolute alcohol (x2) and then cleared with xylene (x3).

H\&E stain: Buccalcell sample was flooded with accustain formalinfree fixative and left for about 30 seconds and rinsed briefly with tap water. The slide was then flooded with about three drops of Haematoxylin and left for about 10 minutes. After 10 minutes acid alcohol was replaced onto the slide and left for about 30 seconds and then replaced with Di-sodium hydrogen orthophosphate solution then left for about 1 minute. The slide was then rinsed briefly with tap water and flooded with Eosin and left for about 30 seconds and then again rinsed with tap water. The slide was the placed onto a hotplate for about $50^{\circ} \mathrm{C}$ until dry, the same was carried out for a penile cell samples.

\section{Cell smearing}

An addition 10 swabs were collected and then were smeared onto the microscope slide directly and then placed onto a hotplate to dry for about 2 minutes at $50^{\circ} \mathrm{C}$. Then on each slide the three staining 
procedures were applied onto the each three slides. Again these were dried onto a hotplate and left to dry before they were examined microscopically. This method was repeated twice to replicate results.

\section{Cell combining}

Each penile swab was smeared onto a microscopic slide then combined with a buccal swab on the same slide. The slide was then dried onto a hotplate for about 2 minutes at $50^{\circ} \mathrm{C}$ and left to cool. A total of 3 combined slides were prepared therefore 3 penile and buccal cells were used for this particular method. Once the slides were cool enough, each slide was stained using chlorine solution and then applying H\&E and Pap stain. The slides were then placed onto a hotplate to dry for about 2 minutes at $50^{\circ} \mathrm{C}$. When all slides were stained and dried from the hotplate, they were all mounted using Entellan Mounting Media by placing a small drop around the area of cells and then placing a cover slip on top. Slides were left in fume cupboard overnight before microscopic analysis.

\section{Microscopic analysis}

Slides were placed onto a microscope and adjusted to $400 \mathrm{x}$ magnification. Each section of the cell was examined to observe the cell morphology of each cell and recorded the observations by capturing using digital camera attached to a microscope.

\section{Results}

In total about 40 slides were made. When all the cells were extracted and stained with each of the three stains there was no cells present when the slides were observed under high power microscope at 400x magnification as indicated in Figure 1. One of the slides that were examined under microscope could have had presence of cells from the extraction method are shown in Figure 1(a) But this was very difficult to determine as it could have been very faint layers of single cells. Whereas for Figure 1(b). These were iodine crystals. However when the method was altered after failure to see any cells by using the extraction method, cell smearing method was then applied to the other samples and the results showed presence of buccal cells in Figure 2. The images in Figure 2(a) Is buccal smear slide showing dark intense pink positive stained cells by H\&E Figure 2(b) Is buccal smear slide with a greenish-brown positive stain and Figure 2(c) buccal smear showing a light brown chocolate colour positive stained cells. When this method worked for positive stained cells, the two type of cell were then combined together and results are shown in Figure 3. There was unknown positive stained cells with purple-ish colour as shown in Figure 3(c) and Figure 3(d). After observing several cells, the numbers of cells were also recorded in Table 2 .

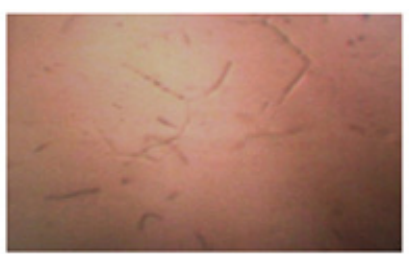

(a)

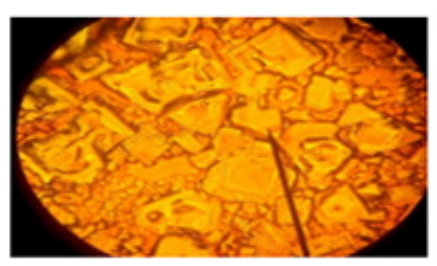

(b)
Figure I Showing the microscopic observations for extraction of cells. (a) Microscopic photo of sample 268385 buccal cell and (b) penile sample the second repeat of the experiment.

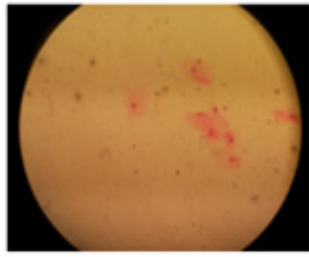

(a)

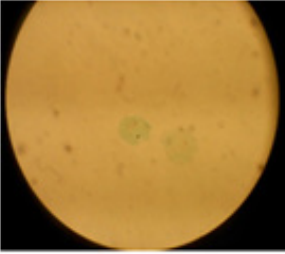

(b)

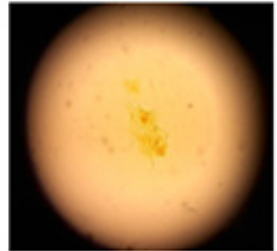

(c)
Figure 2 Showing smeared buccal cells after applying all three staining techniques (a) H\&E stain (b) Pap stain (c) Lugol's iodine.

Table 2 shows all the number of cells found in this investigation and these were a total of 515 cells. Buccal smears were found to contain positive stained cells when all methods were applied and these were 13 buccal positive stained cells for Lugol's iodine, 18 for Pap stain and 120 for H\&E stain. There was no positive penile smeared cell on all stains. The cells that were combined there was no cells for Lugol's iodine. Pap stain had 108 positive stained buccal cells, with 71 unknown positive stained cells which could be penile cells.

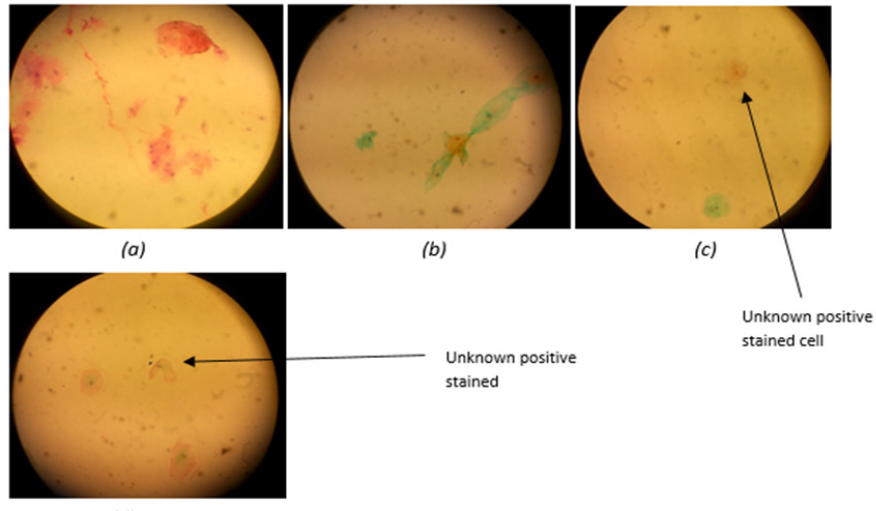

(d)

Figure 3 Showing photos of combined positive stained cells taken under high power microscope (400x). (a) H\&E stain and (b, c \& d) Pap stain.

\section{Discussion}

The purpose of this research was to develop a method that can distinguish between penile and buccal cells. To our knowledge, this was the first research study to describe the histological staining techniques that could allow forensic scientists to distinguish between penile and buccal cells that are possible to transfer after unconsensual sexual activity in reported sexual offenses. This study looked at extracting cells first by using water and then applying the Lugol's Iodine, Pap and H\&E stain. In the first experiment, swabs were cut around the sides and at the bottom using a scalpel then placed in an eppendorff tube. Eppendorff tubes are preferable when extracting cells because of its two tubes. The one with the hole at the bottom end is where the piece of cotton from the swab was placed into and the other one us were all the extracts were collected from at the bottom of the tube and then extracted as mentioned in the methods. This was done for 3 buccal samples and 3 penile samples, then each stain was applied onto each different slide. These was carried out so that each slide can be observed separately under high power microscope and then record the observations. Hence, in total these were 6 samples each stained with Lugo's Iodine, Pap and H\&E stain. Moreover, when slides were 
observed under high powered microscope at 400x magnification, there was hardly any cell on the slides as presented in Table 1. Sample slide ID 996161 penile cells and 268385 buccal cells showed coating which could have indicated the presence of penile and buccal cells but this was later confirmed to be just debris as shown in Figure 1(a).
However, even when the methods were repeated, similar observations were seen on each slides only that this time Lugol's iodine showed presence of iodine crystals which were due to heat from the hotplate in Figure 1(b).

Table I Showing the results produced from the very first experiment using the cell extraction method after repeating the experiment twice and whether they was any negative (-ve) or positive (+ve) cells

\begin{tabular}{|c|c|c|c|c|}
\hline Sample ID & Sample Type & Chlorine Solution (ve/+ve) & Papanicolaou Stain (ve/+ve) & H\&E Stain (-ve/+ve) \\
\hline 238136 & Penile & -ve & -ve & -ve \\
\hline 996161 & Penile & -ve & -ve & Possible cells but very light \\
\hline 643382 & Penile & -ve & -ve & -ve \\
\hline 110622 & Penile & -ve & -ve & -ve \\
\hline 989982 & Penile & -ve & -ve & -ve \\
\hline 950638 & Buccal & -ve & -ve & -ve \\
\hline 372356 & Buccal & -ve & -ve & -ve \\
\hline 389670 & Buccal & -ve & -ve & -ve \\
\hline 754761 & Buccal & -ve & -ve & -ve \\
\hline 268385 & Buccal & -ve & $-v e$ & Showed very light possible presence of cells \\
\hline
\end{tabular}

Table 2 The table below presents the amount of positive stained cells overall found on smeared cells and their colour under high powered microscope

\begin{tabular}{|c|c|c|c|c|c|c|}
\hline \multirow{2}{*}{ Histological Stain } & \multicolumn{2}{|c|}{ No. of +ve Smeared Cells } & \multicolumn{2}{|c|}{ No. of Combined +ve Cells } & \multicolumn{2}{|c|}{ Colour of +ve Stained Cells } \\
\hline & Penile & Buccal & Penile & Buccal & Penile & Buccal \\
\hline Lugol's lodine & 0 & 13 & 0 & 0 & No stain & Light chocolate brown \\
\hline Pap Stain & 0 & 18 & 7I Unknown & 108 & Light purplish colour & $\begin{array}{l}\text { Greenish, sometimes } \\
\text { brown coating }\end{array}$ \\
\hline H\&E & 0 & 120 & 0 & 185 & No stain & Very intense dark pink \\
\hline Sub-total & $|5|$ & & 364 & & Overall total & 515 \\
\hline
\end{tabular}

As a result, at this point of our research, the results did not occur as expected and the presences of penile and buccal cells were unsuccessful when all three staining techniques were applied after cell extraction with water. Research studies carried out by Randall, ${ }^{23}$ Hausmann et al. ${ }^{24}$ explained that when buccal cells are extracted using water, this would lower the glycogen levels present in the cells which is a key content in cells that binds to iodine molecules to give a chocolate brown colour. Furthermore, this scientific phenomenon is derived from the fact that when swabs are left out to dry on swabs for long periods of time, the concentration of amylase increases while cellular membranes are being stressed or broken. ${ }^{24}$ Therefore when cells are extracted, these broken membranes will allow diffusion of amylase to have access to the lower levels of glycogen hence no cells will be present after applying any staining methods. ${ }^{23}$ According to a similar research study published by Jones et al., ${ }^{8}$ they discovered this phenomenon true when they extracted buccal cells with water and found no cells present after applying Lugol's Iodine. However the studies carried out by Jones et al., ${ }^{8}$ Randall, ${ }^{23}$ Hausmann ${ }^{24}$ were only examined for buccal cells and not penile cells thus for these reasons, it is challenging to justify whether the scientific phenomenon also occurs when penile cells are extracted with water since there is no current research to this present time relating to penile cells.
On the other hand, when the methods were altered by smearing the swabs directly and by combining them onto the slides rather than water extraction, there was some positive results. The photographs in Figure 2(a) were buccal cell smears stained with H\&E stain, Pap stain (b) and Lugol's iodine (c). A total of 153 positive stained cells in buccal smears were found as presented in Table 2. 13 of these were from Lugol's iodine stain with a light brown chocolate colour, 18 were positive Pap stained cells with a green-brown colour and 123 were H\&E positive stained cells with intense pinkish colour. When penile swabs were smeared onto slides, for an unexplained reason, there was no presence any positive stained penile cells after applying all three stains even after repeating the experiment. However what was extraordinary was that when the two cells were combined and stained using Pap stain, there was various positive unknown coloured stained cells and 71 of these were found as shown in Figure 3(c) and Figure 3(d). Even though not all the three stains succeeded to positively distinguish between penile and buccal cells, Pap stain was found to be the most conclusive technique that differentiated between the two based on the presence of greenish and purplish stain as shown in Figure 3 and were observed in all combined cells stained with Pap stain. Furthermore, in order to be accurate and precise with the findings, buccal positive smeared cells were further compared under 
comparison microscope with combined cells to examine whether the purplish unknown positive stained cells were also present in buccal smears, and the end result was that they only occurred in combined cells.

However the question comes to how do we know these are penile cells? Why are they only positively stained when they are combined with buccal cells? As of now there is no current research that has described the presence of penile cells using Pap stain and the colour it would show after applying the stain. However a study conducted by $^{21}$ can relate to this research where he looked at the procedure for staining vaginal smears. It appeared that the staining of the cytoplasm on vaginal smear cells was similar with a purplish colour as seen in this research. More so he further investigated the structure of vaginal epithelial cells and it appeared that they consisted of three layers cells known as squamous cells. ${ }^{25}$ The largest of the three are superficial cells and they are known to have small pyknotic nuclei and would stain esophilic in the cytoplasm. The intermediate cells stain basophilic in the cytoplasm and are slightly smaller but with a larger round nuclei. The more rounded, immature cell type located beneath intermediate cells are the parabasal cells. ${ }^{25,26}$

As a result, the unknown stains in Figure 3 could potentially be superficial cells from deposited penile smears on the slide since it has been known that vaginal and penile cells from the male urinary are morphologically similar with Lugol's iodine stated by ${ }^{24}$ In a further study by the same authors, Haunsamann et al., ${ }^{24}$ they looked at the specificity of Lugol's iodine for the detection of vaginal epithelial cells on penile swabs. Their results showed that $50 \%$ of cases studied, glycogenated cells were found on male penile swabs after having sexual intercourse. They later discovered polygonal nucleated cells e.g. superficial cells showing positive Lugol's reaction which could have be an indication of penile cells. However, when the same was found to be positive in the male efferent urinary tract giving a brown chocolate colour positive stain, Lugol's iodine was disclosed not suitable to forensically determine vaginal epithelial cells on penis specimens following sexual intercourse. ${ }^{15}$

Moreover, unconsensual sexual intercourse does not only occur from penile to vaginal penetration and can occur through oral intercourse in sexual offenses. ${ }^{20}$ Penile cells found on a victims buccal swab or buccal cells found on a suspects penile swab can provide forensic scientists and police investigators about the events that occurred during a sexual assault on the victim, hence such potential evidence can provide useful information to support whether or not the evidence indicates that oral sexual intercourse had occurred. ${ }^{18}$ Even with new the current emerging techniques such as Y-STR profiling, which fundamentally looks at the male $\mathrm{Y}$ chromosomes from intimate swabs and produces a profile specific to that type of cell, the technique has been useful in sexual offenses to identify a male perpetrator and has shown positive results from previous research. ${ }^{16,17}$ However such methods still cannot indicate whether the profile is obtained from the male buccal or penile cells because the same issue could still occur when digital penetration has occurred since research has shown that male skin cells could transfer in the act, therefore it would be difficult to determine where these cells have originated from in sexual offence. ${ }^{27,28}$ Similar studies have also shown the reliability and sensitivity the use of Y-STRs in sexual offenses when the presence of spermatozoa is not present. ${ }^{29-31}$ Their research suggested that cytological methods were applied only for the presence of spermatozoa and these were negative. Taking this into account suggests that the demand for developing a method to distinguish between epithelial cells as forensic evidence has not been taken considerably serious in sexual offenses and these are the current issues forensic science is facing up to date. Y-STR techniques are very useful however they cannot provide forensic scientist enough evidence to support whether or not the acts of the offence were vaginal, oral or digital penetration. Therefore from a different perspective, the use of both histological staining techniques and the use Y-STRs play a vital role when investigating sexual assault cases because the victim could argue in court, for example, state that the perpetrator raped them via vaginal penetration when the actual event could have been just oral or digital penetration since skin cells will also likely to transfer in case a Y-STR profile is obtained. For that reason having conclusive techniques that can distinguish between epithelial cells that are likely to transfer during sexual offenses is very important when there is enough evidence to proceed to court which alternatively can increase the evidential value of sexual offenses.

Similarly, another staining technique called aceto-orcien which visualises densely stained chromatin bodies present in female cells and has proven to be effective on buccal smeared cells by. ${ }^{19}$ The technique could be applied in forensic laboratories in sexual offenses, but questions again would arise. For example, a penile swab has been collected from a potential suspect and the cells have stained indicating some female cells, where are these cells coming from? Vaginal or buccal? The answer for these questions again proves where forensic science is still lacking conclusive techniques in sexual offenses that can distinguish, identify and indicate exactly what sort of unconsensual sexual events occurred on the day because the offense could have either been oral or penile penetration. ${ }^{20}$

As a result, the likelihood of finding epithelial cells on a buccal or penile swab collected from either a suspect or victim or both, is dependent on the time elapsed since the incidence and the collection of forensic evidence. According to Wardle, ${ }^{9}$ the author illustrates the different time intervals needed to test cellular material after a sexual offence has occurred and stated, that the collection of penile and buccal cells should not be any longer than 48 hours after the incident. Nevertheless, the collection of penile and buccal cells as evidence is determined by the victim's corporation with the police and centres such as SARCs, were they have specialised forensic medical examiners to collect forensic evidence and this is where problems also occur in sexual offenses. ${ }^{32}$ Female victims are known to be psychologically traumatised after experiencing such activity and can sometimes make them feel ashamed when asked to recall past events or report to the police. ${ }^{9}$ This is why centres such as SARCs need to be more available and accessible for victims because there's a sense of feeling that not many victims are aware of such services and therefore most sexual offense cases are either reported late where the forensic evidence is not reliable anymore or not reported all. ${ }^{9,32}$ Female victims would normally report to the police, but not all police forces will have forensic medical examiners or trained staff available ready to collect forensic evidence from the victim. For these reasons, victims will need to be escorted to the nearest SARC centres for immediate forensic evidence recovery. Hence police forces need to be aware of the sensitivity and the potential of such forensic evidence like epithelial cells by acting immediately and accordingly because any time delay can affect the forensic value of evidence. .,12,32 $^{2}$

In a survey that was conducted by Ingemann-Hansen et al., ${ }^{33}$ 307 alleged victims of sexual violence reported to the police. $11 \%$ turned out to be flase allegations and $19 \%$ of all cases ending with 
sentencing the defendant. However the cases reported were classified as attempted rape by the police and were not seen at the SARCs and no medical check up was carried out by the forensic medical examiners despite victims reported without delay. The survey illustrates that the evidence regarding sexual assault cases not taken considerably serious since the victims could have potential evidence such as penile or buccal cells which could have increased the evidential value. Thefore having forensic evidence in place, the forensic scientist/examiner acts as the expert witness. ${ }^{34}$ In another study by Eurom, et al., (2001), they conducted a population based method were they reviewed all sexual offenses reported during a two year period. Out of the 821 sexual assault reported, forensic examinations were performed in 801 and out the 801 , only $44 \%$ of them a suspect was identified from forensic examinations. However out of the 271 suspects arrested only 89 were found guilty and most with charges dropped or case files gone missing. It was reported in the study that 445 cases were reported with no suspect which is a vast number due to lack of evidence. Majority of the cases had documented files which included abrasions, conclusions, lacerations and bite marks. Bite marks could possibly contain amylase hence buccal cells, which could be used to identify potential suspects by carrying out staining methods to differentiate between buccal and skin cells. ${ }^{7}$ In addition Y-STR profiling for targeting male cells would have also strengthen the evidential value in all these cases. ${ }^{16}$ The problem again goes back to the fact that other sources of evidence were not taken into consideration in these cases such as collection of buccal, penile or vaginal swabs hence the purpose of this research to illustrate the demand for the examining biological evidence such as penile and buccal cells.

Moreover, the demand for distinguishing between epithelial cells is not the only issue involving sexual offenses, the recovery of these cells is is also important. For many years, cotton swabs have been the traditional way used by forensic investigators to collect biological material at crimes scenes or from victims and suspects until an article published online, were forensic professionals redesigned a product for DNA recovery called mini popule..$^{35}$ The mini popule has larger heads than traditional swabs that allow easy sampling for larger areas which can maximise collection of cells. They have been described to be self-saturating foam swabs produced by medical company. The mini-popule heads are attached to a hollow handle filled with $91 \%$ isopropanol. When the handle is squeezed a seal inside is broken which allows the isopropanol to form into a foam. The device was tested out and produced significantly better results of trace DNA compared to traditional swabs. However, the costs are high and heat-sealed foam heads can be difficult to remove from the handles. The device also had larger foam heads that had to be cut into smaller pieces to carry out DNA extraction hence increasing time and potential contamination. This device could potentially by applicable in sexaul assault cases since the majority if time DNA extraction would not be needed, but the device is able to retain more cells, for example collecting penile cells from a male suspect. In addtion this device eliminates the concept that the concentration of amylase increases when swabs when left out to dry in cases were buccal cells could be present on a penile swabs is a sexual assault case. ${ }^{23,24,36}$

\section{Conclusion}

Overall, this has been the first research that has looked at distinguishing between penile and buccal cells by using histological staining methods. Epithelial cells are known to commonly transfer between the victim and the perpetrator in sexual offenses therefore, in regards to other research that have conducted similar methods, sexual offenses in forensic science still had issues regarding the evidence involved because of its complexities. The several experiments carried out in this research have shown both some negative and positive aspects. For instance, it is now known that extracting cells using water is not recommended since water lowers the glycogen levels present in cells which binds to the specific stain, hence why they was negative stained cells and previous research has proven this to be factual. The combination of the two cells on a microscope slide is unique technique that has not been used before in all previous research relating to sexual offenses since in realife, a penile swab from a suspect will likely to contain both cells, therefore makes this research carried out in a more realistic way. A total of 364 combined positive cells were found, with 71 unknown positive stained cells which could be indication of penile cells.

However for effective results in real life forensic casework, the victim's collaboration with the police, accessing centres such as SARCs and the time delay will play a major role in to forensically support the whether or not they was unconsensual contact between the victim and the perpetrator. Police forces and SARCs need to alert victims to always come forward straight after an incidence, and that even though it may seem the criminal justice system is unrelialable, there is still chances for justice because sexual offenses seem to be increasing while the number of perpetrators convicted decreasing due to lack of evidence. In addition, this research should be repeated by using the same staining methods or other stains to try obtain positive stained penile cells, since this research could not explain to why the presence of penile cells only showed after combining them with buccal cells. Therefore future research is still needed in order to explain this phenomenon. However with the results from this paper, Pap stain could be a potential method to distinguish between penile and buccal cells recovered from a sexual offense in forensic casework.

\section{Acknowledgments}

None.

\section{Conflicts of interest}

None.

\section{References}

1. Archard D. Sexual Consent. Colarado: Westview Press, USA, 1998; pp. $1-189$.

2. Futter S, Mebane W. The effects of rape law reform on rape case processing. Berkeley Women's Law Journal . 2013;16:72-139.

3. Harris J, Grace S. A Question of Evidence? Investigating and Prosecuting Rape in the 1990s. London: Home Office, UK, 1990;pp. 1-84.

4. Temkin J. "And always keep a hold of nurse, for fear of finding something worse": Challenging rape myths in the courtroom. New Criminal Law Review. 2010;3(4):710-734.

5. Dinos S, Burrowes N, Hammond K, et al. A systematic review of juries' assessment of rape victims: Do rape myths impact on juror decisionmaking? International Journal of Law. Crime and Justice. 2015;43(1): $36-49$.

6. Chen J, Kobilinsky L, Wolosin D, et al. A Physical Method for Seperating Spermatozoa from Epithelial Cells in Sexual Assault Evidence. J Forensic Sci. 1998;43(1):114-118.

7. French CE, Jensen CG, Vintiner SK, et al. A novel histological technique for distinguishing between epithelial cells in forensic casework. Forensic Sci Int. 2008;178(1):1-6. 
8. Jones EL, Leon JA. Lugol's Test Reexamined again: Buccal Cells. $J$ Forensic Sci. 2004;49(1):64-67.

9. Wardle S. Sexual assault: examination of the victim. Medicine. 2014;42(6):318-322.

10. Cybulska B, Forster G. Sexual assault: examination of the victim. Medicine 38(5): 235-238.

11. The National Center for Women and Policing, (2001) Successfully Investigating Acquaintance Sexual Assault, USA, pp. 2010; 1-22.

12. Cartwright PS, Moore RA, Anderson JR, et al. Gential injury and implied consent tp alleged rape. J Reprod Med. 1986;31(11):1043-1044.

13. Office for National Statistics. An Overview of Sexual Offending in England and Wales. Ministry of Justice, Home Office and the Office for National Statistics, UK, 2013; pp. 1-73.

14. Hausmann R, Pregler C, Schellmann B. The value of the Lugol's iodine staining technique for the identification of vaginal epithelial cells. Int $J$ Legal Med. 1994;106(6):298-301.

15. Dettermeyer R. Detection of Vaginal Epithelial Cells. In: Forensic Histopathology. Springer Heidelberg Dordrecht, USA, 2011; pp. 1-365.

16. Betz A, Bässler G, Dietl G, et al. DYS STR analysis with epithelial cells in a rape case. Forensic Sci Int. 2001;118(2-3):126-136.

17. Drobnic K. Anaylsis of DNA Evidence Recovered from Epithelial Cells in Penile Swabs. Croat Med J. 2003;44(3):350-354.

18. Keating SM. Information from penile swabs in sexual assault cases. Forensic Sci Int. 1989;43(1):63-81.

19. Renard S. Determination of Sex of Exfoliated Epithelial Cells and its Significance in Forensic Science. J Forensic Sci Soc. 1971;11(1):15-20.

20. Keating SM, Higgs DF. Oral Sex - further information from sexual cases. J Forensic Sci Soc. 1992;32(4):327-331.

21. Papanicolaou GN. A new procedure for staining vaginal smears. Science. 1942;95(2469):438-439.

22. Sawa M, Yabuki A, Miyoshi N, et al. Rapid-Air-Dry Papanicolaou Stain in Canine and Feline Tumor Cytology:A Quantitative Comparison with the Giemsa Stain. J Vet Med Sci. 2012;74(9):1133-1138.

23. Randall B. Glycogenated Squamous Epithelial Cells as a Marker of Foreign Body Penetration in Sexual Assault. J Forensic Sci. 1988;33(2):511-514.

24. Hausmann R, Schellmann B. Forensic value of the Lugol's staininng method: furhter studiees on glycogneated epithelium in the male urinary tract. Int J Legal Med. 1994;107(3):147-151.
25. McKenna NJ, Lanz RB, O’Malley BW. Nuclear receptor coregulators: cellular and molecular biology. Endocr Rev. 1999;20(3):321-344.

26. Thornton MJ. The biological actions of estogens on skin. Exp Dermatol. 2002;11(6):487-502.

27. Murray C, McAlister C, Elliott K. Identification and isolation of male cells using fluorescence in situ hybridisation and laser microdissection, for use in the investigation of sexual assault. Forensic Forensic Sci Int Genet. 2007;1(3-4):247-252.

28. McDonald A, Jones E, Lewis J, et al. Y-STR analysis of digital and/or penile penetration cases with no detected spermatozoa. Forensic Sci Int Genet. 201515:84-89.

29. Sibille I, Duverneuil C, Lorin de la Grandmaison G, et al. Y-STR DNA amplification as biological evidence in sexually assaulted female victims with no cytological detection of spermatozoa. Forensic Sci Int. 2002;125(2-3):212-216.

30. Johnson CL, Giles RC, Warren JH, et al. Analysis of non-suspect samples lacking visually identifiable sperm using Y-STR 10-pex. J Forensic Sci. 2005;50(5):1116-1118.

31. Neuhuber F. The efficiency of $\mathrm{Y}$-chromosome markers in forensic trace analysis and their inclusions in the Austrian National DNA Database. Forensic Science International: Genetics Supplements Series. 2013;4(1): $172-173$.

32. Newton M. The forensic aspects of sexual violence. Best Pract Res Clin Obstet Gynaecol. 2013;27(1):77-90.

33. Ingemann-Hansen $\mathrm{O}$, Brink $\mathrm{O}$, Sabroe $\mathrm{S}$, et al. Legal aspects of sexual violence-Does forensic evidence make a difference? Forensic Sci Int 2008;180(2-3):98-104.

34. Spears J, Spohn C. The effect of evidence factors and victim characteristics on prosecutors charging decisions in sexual assualt cases. Justice Quarterly. 1997;14(3):501-524.

35. Collopy C. Mini-Popule Developed to Maximize DNA Recovery for Robotic Forensic Analysis. Forensic Magzine. 2008;2(1): 1-4.

36. UK Parliament. Sexual Offences Act2003: Chapter 42, UK, 2003; pp. $1-129$. 